\title{
Antioxidant activity, total phenolic and total flavonoid contents of whole plant extracts Torilis leptophylla L
}

Naima Saeed ${ }^{\dagger}$, Muhammad R Khan $^{*}$ and Maria Shabbir ${ }^{\dagger}$

\begin{abstract}
Background: The aim of this study was to screen various solvent extracts of whole plant of Torilis leptophylla to display potent antioxidant activity in vitro and in vivo, total phenolic and flavonoid contents in order to find possible sources for future novel antioxidants in food and pharmaceutical formulations.

Material and methods: A detailed study was performed on the antioxidant activity of the methanol extract of whole plant of Torilis leptophylla (TLM) and its derived fractions $\{n$-hexane (TLH), chloroform (TLC) ethyl acetate (TLE) $n$-butanol (TLB) and residual aqueous fraction (TLA)\} by in vitro chemical analyses and carbon tetrachloride $\left(\mathrm{CCl}_{4}\right)$ induced hepatic injuries (lipid peroxidation and glutathione contents) in male Sprague-Dawley rat. The total yield, total phenolic (TPC) and total flavonoid contents (TFC) of all the fractions were also determined. TLM was also subjected to preliminary phytochemical screening test for various constituents.

Results: The total phenolic contents (TPC) (121.9 $\pm 3.1 \mathrm{mg} \mathrm{GAE} / \mathrm{g}$ extract) of TLM while total flavonoid contents (TFC) of TLE $(60.9 \pm 2.2 \mathrm{mg}$ RTE/g extract) were found significantly higher as compared to other solvent fractions. Phytochemical screening of TLM revealed the presence of alkaloids, anthraquinones, cardiac glycosides, coumarins, flavonoids, saponins, phlobatannins, tannins and terpenoids. The $\mathrm{EC}_{50}$ values based on the DPPH $(41.0 \pm 1 \mu \mathrm{g} / \mathrm{ml})$, ABTS $(10.0 \pm 0.9 \mu \mathrm{g} / \mathrm{ml})$ and phosphomolybdate $(10.7 \pm 2 \mu \mathrm{g} / \mathrm{ml})$ for TLB, hydroxyl radicals $(8.0 \pm 1 \mu \mathrm{g} / \mathrm{ml})$ for TLC, superoxide radicals $(57.0 \pm 0.3 \mu \mathrm{g} / \mathrm{ml})$ for TLM and hydrogen peroxide radicals $(68.0 \pm 2 \mu \mathrm{g} / \mathrm{ml})$ for TLE were generally lower showing potential antioxidant properties. A significant but marginal positive correlation was found between TPC and $\mathrm{EC}_{50}$ values for DPPH, hydroxyl, phosphomolybdate and ABTS, whereas another weak and positive correlation was determined between TFC and $\mathrm{EC}_{50}$ values for superoxide anion and hydroxyl radicals. Results of in vivo experiment revealed that administration of $\mathrm{CCl}_{4}$ caused a significant increase in lipid peroxidation (TBARS) while decrease in GSH contents of liver. In contrast, TLM (200 mg/kg bw) and silymarin ( $50 \mathrm{mg} / \mathrm{kg}$ bw) co-treatment effectively prevented these alterations and maintained the antioxidant status.
\end{abstract}

Conclusion: Data from present results revealed that Torilis leptophylla act as an antioxidant agent due to its free radical scavenging and cytoprotective activity.

Keywords: Torilis leptophylla, DPPH, Antioxidant, Oxidative stress, TBARS

\footnotetext{
* Correspondence: mrkhanqau@yahoo.com

${ }^{\dagger}$ Equal contributors

Department of Biochemistry, Faculty of Biological Sciences, Quaid-i-Azam

University, Islamabad 45320, Pakistan
} 


\section{Background}

Since very old times, herbal medications have been used for relief of symptoms of disease [1]. Despite the great advances observed in modern medicine in recent decades, plants still make an important contribution to health care. Much interest, in medicinal plants however, emanates from their long use in folk medicines as well as their prophylactic properties, especially in developing countries. Large number of medicinal plants has been investigated for their antioxidant properties. Natural antioxidants either in the form of raw extracts or their chemical constituents are very effective to prevent the destructive processes caused by oxidative stress [2]. Although the toxicity profile of most medicinal plants have not been thoroughly evaluated, it is generally accepted that medicines derived from plant products are safer than their synthetic counterparts $[3,4]$.

Substantial evidence has accumulated and indicated key roles for reactive oxygen species (ROS) and other oxidants in causing numerous disorders and diseases. The evidence has brought the attention of scientists to an appreciation of antioxidants for prevention and treatment of diseases, and maintenance of human health [5]. Human body has an inherent antioxidative mechanism and many of the biological functions such as the antimutagenic, anti-carcinogenic, and anti-aging responses originate from this property [6,7]. Antioxidants stabilize or deactivate free radicals, often before they attack targets in biological cells [8]. Recently interest in naturally occurring antioxidants has considerably increased for use in food, cosmetic and pharmaceutical products, because they possess multifacetedness in their multitude and magnitude of activity and provide enormous scope in correcting imbalance $[9,10]$.

The role of free radical reactions in disease pathology is well established and is known to be involved in many acute and chronic disorders in human beings, such as diabetes, atherosclerosis, aging, immunosuppression and neurodegeneration [11]. An imbalance between ROS and the inherent antioxidant capacity of the body, directed the use of dietary and /or medicinal supplements particularly during the disease attack. Studies on herbal plants, vegetables, and fruits have indicated the presence of antioxidants such as phenolics, flavonoids, tannins, and proanthocyanidins. The antioxidant contents of medicinal plants may contribute to the protection they offer from disease. The ingestion of natural antioxidants has been inversely associated with morbidity and mortality from degenerative disorders [6]. Liver diseases remain a serious health problem. It is well known that free radicals cause cell damage through mechanisms of covalent binding and lipid peroxidation with subsequent tissue injury. Antioxidant agents of natural origin have attracted special interest because of their free radical scavenging abilities [12]. The use of medicinal plants with high level of antioxidant constituents has been proposed as an effective therapeutic approach for hepatic damages [13].

Torilis leptophylla belonging to the Apiaceae family [14] or more commonly known as Bristle fruit Hedge parsley, is a forb of the genus Torilis, distributed in Asia, Europe and North Africa. It is represented in Iran by nine species [15]. T. leptophylla has been used in folk medicine for the treatment of gastrointestinal illnesses in Iran and Pakistan. The plant is highly effective against some pathogens thus confirming its use as disinfectant or antiseptic [16].

The search for novel natural antioxidants of plant origin has ever since increased. It is not known which constituents of plant are associated in reducing the risk of chronic diseases, but antioxidants appear to play a major role in the protective effect of plant medicine. The present study was designed to investigate the TPC and TFC and to evaluate the antioxidant activities (in vitro and in vivo) of the various fractions of methanol extract of whole plant of T. leptophylla. The $95 \%$ methanol extract was also subjected to phytochemical screening to determine the presence of alkaloids, anthraquinones, cardiac glycosides, coumarins, flavonoids, saponins, phlobatannins, tannins and terpenoids.

\section{Methods}

\section{Plant collection}

The plant was collected in April 2011 from Islamabad, Pakistan. The plant material was botanically identified by Dr. Mir Ajab Khan, Department of Plant Sciences, Quaid-i-Azam University Islamabad. A voucher specimen (accession \#023541) was deposited at the Herbarium of Pakistan Museum of Natural History Islamabad.

\section{Extract preparation}

The fresh, whole plant (3 kg) was collected and shade dried to obtain 500 g dry sample which was later coarsely powdered in a Willy Mill to 60-mesh size and used for solvent extraction. For sample preparation, $500 \mathrm{~g}$ of dried sample were extracted twice (2000 $\mathrm{ml}$ for each) with $95 \%$ methanol at $25^{\circ} \mathrm{C}$ for $48 \mathrm{~h}$ and concentrated using a rotary evaporator (Panchun Scientific Co., Kaohsiung, Taiwan) under reduced pressure at $40^{\circ} \mathrm{C}$ to yield the TLM (11.5\%). The residue was suspended in water $(50 \mathrm{ml})$ and partitioned successively with $n$-hexane, chloroform, ethyl acetate, $n$-butanol (a total of two aliquots of $100 \mathrm{ml}$ each) and soluble residual aqueous fraction yielding respectively the TLH (5.4\%), TLC (4.3\%), TLE (6.1\%), TLB (4.8\%) and TLA (8.2\%) [17].

\section{Chemicals}

Ascorbic acid; aluminum chloride, 2, 2' - azino-bis-(3ethylbenzothiazoline-6-sulphonic acid) (ABTS); ferric 
chloride $\left(\mathrm{FeCl}_{3}\right)$; Folin-Ciocalteu; bovine serum albumin (BSA); potassium persulphate; 2,2'-diphenyl-1-picrylhydrazyl (DPPH); nitro blue tetrazolium (NBT); phenazine methosulphate (PMS); reduced glutathione (GSH); 1,2dithio-bis nitro benzoic acid (DTNB); sulphosalicylic acid; thiobarbituric acid (TBA) and trichloroacetic acid (TCA) were purchased from Sigma Co. (St. Louis, MO, USA). Sulphuric acid; 2-deoxyribose; riboflavin; sodium carbonate $\left(\mathrm{Na}_{2} \mathrm{CO}_{3}\right)$; sodium hydroxide $(\mathrm{NaOH})$; sodium nitrite $\left(\mathrm{NaNO}_{2}\right)$; disodium hydrogen phosphate $\left(\mathrm{Na}_{2} \mathrm{HPO}_{4}\right)$ and hydrogen peroxide $\left(\mathrm{H}_{2} \mathrm{O}_{2}\right)$ were obtained from Wako Co. (Osaka, Japan). Potassium ferricyanide $\left[\mathrm{K}_{3} \mathrm{Fe}(\mathrm{CN})_{6}\right]$; triflouroacetic acid; sodium dihydrogen phosphate $\left(\mathrm{NaH}_{2} \mathrm{PO}_{4}\right)$ and all solvents $n$-hexane (99.8\%); chloroform (99.8\%); ethyl acetate (99.8\%) and $n$-butanol (99.8\%) used were of analytical grade and purchased from Merck Co. (Darmstadt, Germany). Distilled deionized water (dd. $\mathrm{H}_{2} \mathrm{O}$ ) was prepared by Ultrapure TM water purification system (Lotun Co., Ltd., Taipei, Taiwan).

\section{In vitro studies}

\section{Antioxidant assays}

Each sample was dissolved in $95 \%$ methanol to make a concentration of $1 \mathrm{mg} / \mathrm{ml}$ and then diluted to prepare the series concentrations for antioxidant assays. Reference chemicals were used for comparison in all assays.

\section{DPPH radical scavenging activity assay}

The free radical scavenging activity of the fractions was measured in vitro by 2,2'- diphenyl-1-picrylhydrazyl (DPPH) assay according to the method described earlier $[18,19]$. The stock solution was prepared by dissolving $24 \mathrm{mg}$ DPPH with $100 \mathrm{ml}$ methanol and stored at $20^{\circ} \mathrm{C}$ until required. The working solution was obtained by diluting DPPH solution with methanol to attain an absorbance of about $0.98 \pm 0.02$ at $517 \mathrm{~nm}$ using the spectrophotometer. A $3 \mathrm{ml}$ aliquot of this solution was mixed with $100 \mu \mathrm{l}$ of the sample at various concentrations $(10-500 \mu \mathrm{g} / \mathrm{ml})$. The reaction mixture was shaken well and incubated in the dark for $15 \mathrm{~min}$ at room temperature. Then the absorbance was taken at $517 \mathrm{~nm}$. The control was prepared as above without any sample. The scavenging activity was estimated based on the percentage of DPPH radical scavenged as the following equation:

$$
\begin{aligned}
& \text { Scavenging effect }(\%) \\
& =[(\text { control absorbance }- \text { sample absorbance }) \\
& \quad /(\text { control asbsorbance })] \times 100
\end{aligned}
$$

\section{Superoxide anion scavenging assay}

The assay for superoxide anion radical scavenging activity was supported by riboflavin-light-NBT system [20].
Briefly, $1 \mathrm{ml}$ of sample was taken at different concentrations $(25$ to $500 \mu \mathrm{g} / \mathrm{ml}$ ) and mixed with $0.5 \mathrm{ml}$ of phosphate buffer $(50 \mathrm{mM}, \mathrm{pH}$ 7.6), $0.3 \mathrm{ml}$ riboflavin (50 mM), $0.25 \mathrm{ml}$ PMS $(20 \mathrm{mM})$, and $0.1 \mathrm{ml}$ NBT $(0.5 \mathrm{mM})$. Reaction was started by illuminating the reaction mixture using a fluorescent lamp. After $20 \mathrm{~min}$ of incubation, the absorbance was measured at $560 \mathrm{~nm}$. Ascorbic acid was used as standard. The scavenging ability of the plant extract was determined by the following equation:

$$
\begin{aligned}
& \text { Scavenging effect }(\%) \\
& =(1-\text { absorbance of sample } \\
& \quad / \text { absorbance of control }) \times 100
\end{aligned}
$$

\section{Phosphomolybdate assay (total antioxidant capacity)}

The total antioxidant capacity of the fractions was determined by phosphomolybdate method using ascorbic acid as a standard [21]. An aliquot of $0.1 \mathrm{ml}$ of sample solution was mixed with $1 \mathrm{ml}$ of reagent solution $(0.6 \mathrm{M}$ sulphuric acid, $28 \mathrm{mM}$ sodium phosphate and $4 \mathrm{mM}$ ammonium molybdate). The tubes were capped and incubated in a water bath at $95^{\circ} \mathrm{C}$ for $90 \mathrm{~min}$. After the samples had cooled to room temperature, the absorbance of the mixture was measured at $765 \mathrm{~nm}$ against a blank. A typical blank contained $1 \mathrm{ml}$ of the reagent solution and the appropriate volume of the solvent and incubated under the same conditions. Ascorbic acid was used as standard. The antioxidant capacity was estimated using following formula:

$$
\begin{aligned}
& \text { Antioxidant effect }(\%) \\
& =[(\text { control absorbance }- \text { sample absorbance }) \\
& \quad /(\text { control absorbance })] \times 100
\end{aligned}
$$

\section{Hydroxyl radical scavenging assay}

Hydroxyl radical scavenging activity was measured by the ability of the different fractions of T. leptophylla extract to scavenge the hydroxyl radicals generated by the $\mathrm{Fe}^{3}$ ${ }^{+}$-ascorbate-EDTA- $\mathrm{H}_{2} \mathrm{O}_{2}$ system (Fenton reaction) [22]. The reaction mixture contained; $500 \mu \mathrm{l}$ of 2-deoxyribose $(2.8 \mathrm{mM})$ in phosphate buffer $(50 \mathrm{mM}, \mathrm{pH} 7.4), 200 \mu \mathrm{l}$ of premixed ferric chloride $(100 \mathrm{mM})$ and EDTA $(100 \mathrm{mM})$ solution $(1: 1 ; \mathrm{v} / \mathrm{v}), \quad 100 \mu \mathrm{l}$ of $\mathrm{H}_{2} \mathrm{O}_{2}(200 \mathrm{mM})$ with or without the extract solution $(100 \mu \mathrm{l})$. The reaction was triggered by adding $100 \mu \mathrm{l}$ of $300 \mathrm{mM}$ ascorbate and incubated for $1 \mathrm{~h}$ at $37^{\circ} \mathrm{C} .0 .5 \mathrm{ml}$ of the reaction mixture was added to $1 \mathrm{ml}$ of TCA $(2.8 \%$; w/v; aqueous solution), then $1 \mathrm{ml}$ of $1 \%$ aqueous TBA were added to the reaction mixture. The mixture was heated for $15 \mathrm{~min}$ on a boiling water bath. After the mixture being cooled the absorbance at $532 \mathrm{~nm}$ was noted against a blank (the same solution but without reagent). The 
scavenging activity on hydroxyl radical was calculated as follows:

$$
\begin{aligned}
& \text { Scavenging activity }(\%) \\
& =(1-\text { absorbance of sample } \\
& \quad / \text { absorbance of control }) \times 100
\end{aligned}
$$

\section{Hydrogen peroxide scavenging activity}

Hydrogen peroxide solution $(2 \mathrm{mM})$ was prepared in $50 \mathrm{mM}$ phosphate buffer $(\mathrm{pH} 7.4)$. Aliquots $(0.1 \mathrm{ml})$ of different fractions was transferred into the test tubes and their volumes were made up to $0.4 \mathrm{ml}$ with $50 \mathrm{mM}$ phosphate buffer ( $\mathrm{pH} 7.4$ ) After addition of $0.6 \mathrm{ml}$ hydrogen peroxide solution, tubes were vortexed and absorbance of the hydrogen peroxide at $230 \mathrm{~nm}$ was determined after $10 \mathrm{~min}$, against a blank [23]. The abilities to scavenge the hydrogen peroxide were calculated using the following equation:

$$
\begin{aligned}
& \text { Hydrogen peroxide scavenging activity } \\
& =(1-\text { absorbance of sample } \\
& \text { /absorbance of sample }) \times 100
\end{aligned}
$$

\section{ABTS radical scavenging activity}

The 2,2'-azinobis (3-ethylbenzthiazoline-6-sulphonic acid), commonly called ABTS cation scavenging activity was performed [24]. Briefly, ABTS solution (7 mM) was reacted with potassium persulfate $(2.45 \mathrm{mM})$ solution and kept for overnight in the dark to yield a dark coloured solution containing ABTS radical cations. Prior to use in the assay, the ABTS radical cation was diluted with $50 \%$ methanol for an initial absorbance of about $0.70 \pm 0.02$ at $745 \mathrm{~nm}$, with temperature control set at $30^{\circ} \mathrm{C}$. Free radical scavenging activity was assessed by mixing $300 \mu \mathrm{l}$ of test sample with $3.0 \mathrm{ml}$ of ABTS working standard in a microcuvette. The decrease in absorbance was measured exactly one minute after mixing the solution, then up to $6 \mathrm{~min}$. The percentage inhibition was calculated according to the formula:

$$
\begin{aligned}
& \text { Scavenging effect }(\%) \\
& =[(\text { control absorbance }- \text { sample absorbance }) \\
& \quad /(\text { control asbsorbance })] \times 100
\end{aligned}
$$

The antioxidant capacity of test samples was expressed as $\mathrm{EC}_{50}$ (anti-radical activity), the concentration necessary for $50 \%$ reduction of ABTS [25].

\section{Reducing power}

The reducing power was based on Fe (III) to Fe (II) transformation in the presence of the solvent fractions [26]. The Fe (II) can be monitored by measuring the formation of Perl's Prussian blue at $700 \mathrm{~nm}$. Various concentrations of the sample $(2 \mathrm{ml})$ were mixed with $2 \mathrm{ml}$ of phosphate buffer $(0.2 \mathrm{M}, \mathrm{pH} 6.6)$ and $2 \mathrm{ml}$ of potassium ferricyanide $(10 \mathrm{mg} / \mathrm{ml})$. The mixture was incubated at $50^{\circ} \mathrm{C}$ for $20 \mathrm{~min}$ followed by addition of $2 \mathrm{ml}$ of trichloroacetic acid $(100 \mathrm{mg} / \mathrm{l})$. The mixture was centrifuged at $3000 \mathrm{rpm}$ for $10 \mathrm{~min}$ to collect the upper layer of the solution. A volume of $2 \mathrm{ml}$ from each of the mixture earlier mentioned was mixed with $2 \mathrm{ml}$ of distilled water and $0.4 \mathrm{ml}$ of $0.1 \%(\mathrm{w} / \mathrm{v})$ fresh ferric chloride. After $10 \mathrm{~min}$ reaction, the absorbance was measured at $700 \mathrm{~nm}$. Higher absorbance of the reaction mixture indicates a higher reducing power.

\section{Estimation of total phenolic content}

The total phenolic content was determined by the spectrophotometric method [27]. In brief, a $1 \mathrm{ml}$ of sample $(1 \mathrm{mg} / \mathrm{ml})$ was mixed with $1 \mathrm{ml}$ of Folin-Ciocalteu's phenol reagent. After $5 \mathrm{~min}, 10 \mathrm{ml}$ of a $7 \% \mathrm{Na}_{2} \mathrm{CO}_{3}$ solution was added to the mixture followed by the addition of $13 \mathrm{ml}$ of deionized distilled water and mixed thoroughly. The mixture was kept in the dark for $90 \mathrm{~min}$ at $23^{\circ} \mathrm{C}$, after which the absorbance was read at $750 \mathrm{~nm}$. The TPC was determined from extrapolation of calibration curve which was made by preparing gallic acid solution. The estimation of the phenolic compounds was carried out in triplicate. The TPC was expressed as milligrams of gallic acid equivalents (GAE) per $g$ of dried sample.

\section{Estimation of total flavonoid content}

Total flavonoid content was determined following a method by Park et al (2008) [28]. In a $10 \mathrm{ml}$ test tube, $0.3 \mathrm{ml}$ of extracts, $3.4 \mathrm{ml}$ of $30 \%$ methanol, $0.15 \mathrm{ml}$ of $\mathrm{NaNO}_{2}(0.5 \mathrm{M})$ and $0.15 \mathrm{ml}$ of $\mathrm{AlCl}_{3} \cdot 6 \mathrm{H}_{2} \mathrm{O}(0.3 \mathrm{M})$ were mixed. After $5 \mathrm{~min}, 1 \mathrm{ml}$ of $\mathrm{NaOH}(1 \mathrm{M})$ was added. The solution was mixed well and the absorbance was measured against the reagent blank at $506 \mathrm{~nm}$. The standard curve for total flavonoids was made using rutin standard solution (0 to $100 \mathrm{mg} / \mathrm{l})$ under the same procedure as earlier described. The total flavonoids were expressed as milligrams of rutin equivalents per $g$ of dried fraction.

\section{Phytochemical screening of TLM}

Phytochemical screening of TLM for the presence of alkaloids, anthraquinones, cardiac glycosides, coumarins, flavonoids, saponins, phlobatannins, tannins and terpenoids was carried out.

\section{Test for alkaloids}

$0.4 \mathrm{~g}$ of TLM was stirred with $8 \mathrm{ml}$ of $1 \% \mathrm{HCl}$ and the mixture was warmed and filtered [29]. $2 \mathrm{ml}$ of filtrate was treated separately with (a) with few drops of potassium mercuric iodide (Mayer's reagent) and (b) potassium bismuth (Dragendroff's reagent). Turbidity or precipitation 
with either of these reagents was taken as evidence for existence of alkaloids.

\section{Test for saponins}

The ability of saponins to produce emulsion with oil was used for the screening test [29]. $20 \mathrm{mg}$ of TLM was boiled in $20 \mathrm{ml}$ of distilled water in a water bath for five min and filtered. $10 \mathrm{ml}$ of the filtrate was mixed with $5 \mathrm{ml}$ of distilled water and shaken vigorously for froth formation. 3 drops of olive oil were mixed with froth, shaken vigorously and observed for emulsion development.

\section{Test for terpenoids}

Presence of terpenoids in TLM was carried out by taking $5 \mathrm{ml}(1 \mathrm{mg} / \mathrm{ml})$ of TLM and mixed with $2 \mathrm{ml}$ of chloroform, followed by $3 \mathrm{ml}$ of concentrated $\mathrm{H}_{2} \mathrm{SO}_{4}$. A reddish brown colouration of the interface confirmed the presence of terpenoids [29].

\section{Test for anthraquinones}

$200 \mathrm{mg}$ of TLM was boiled with $6 \mathrm{ml}$ of $1 \% \mathrm{HCl}$ and filtered. The filtrate was shaken with $5 \mathrm{ml}$ of benzene, filtered and $2 \mathrm{ml}$ of $10 \%$ ammonia solution was added to the filtrate. The mixture was shaken and the presence of a pink, violet or red colour in the ammoniacal phase indicated the presence of free hydroxyl anthraquinones [30].

\section{Cardiac glycosides determination}

$5 \mathrm{ml}(10 \mathrm{mg} / \mathrm{ml}$ in methanol) of TLM was mixed with $2 \mathrm{ml}$ of glacial acetic acid having one drop of $\mathrm{FeCl}_{3}$ solution. To the mixture obtained $1 \mathrm{ml}$ of concentrated $\mathrm{H}_{2} \mathrm{SO}_{4}$ was added to form a layer. The presence of brown ring of the interface indicated deoxy sugar characteristic of cardiac glycosides [30].

\section{Test for coumarins}

In a small test tube, $300 \mathrm{mg}$ of TLM was covered with filter paper moistened with $1 \mathrm{~N} \mathrm{NaOH}$. The test tube was placed for few minutes in a boiling water bath. After removing the filter paper it was examined under UV light, yellow florescence indicated the presence of coumarins [30].

\section{Test for phlobatannins}

$80 \mathrm{mg}$ of TLM was boiled in 1\% aqueous hydrochloric acid; the deposition of a red precipitate indicated the presence of phlobatannins [30].

\section{Test for flavonoids}

$50 \mathrm{mg}$ of TLM was suspended in $100 \mathrm{ml}$ of distilled water to get the filtrate. $5 \mathrm{ml}$ of dilute ammonia solution was added to $10 \mathrm{ml}$ of filtrate followed by few drops of concentrated $\mathrm{H}_{2} \mathrm{SO}_{4}$. Presence of flavonoids was confirmed by yellow colouration [31].

\section{Test for tannins}

$50 \mathrm{mg}$ of TLM was boiled in $20 \mathrm{ml}$ of distilled water and filtered. A few drops of $0.1 \% \mathrm{FeCl}_{3}$ was added in filtrate and observed for colour change; brownish green or a blue-black colouration was taken as evidence for the presence of tannins [31].

\section{In vivo studies \\ Animals and treatment}

Studies were carried out using male Sprague Dawley rats weighing $180 \pm 10 \mathrm{~g}$. The animals were grouped and housed in polyacrylic cages with not more than six animals per cage and maintained under standard laboratory conditions. They had free access to standard diet and fresh water ad libitum. For acute toxicity studies, 30 rats were divided randomly into 5 groups, each comprising 6 animals. Group (I) the controls received only vehicles; olive oil $(0.5 \mathrm{ml} / \mathrm{kg} \mathrm{bw})$ and DMSO $(0.5 \mathrm{ml} / \mathrm{kg} \mathrm{bw})$ and fed with a normal diet for 7 days. Group II (induction controls) received single dose of $\mathrm{CCl}_{4}\left(\mathrm{CCl}_{4}+\right.$ Olive oil in 1:1 ratio; $2 \mathrm{ml} / \mathrm{kg}$ bw; i.p) on day 1 and day 7 of the experiment. Group III and IV received TLM $(200 \mathrm{mg} / \mathrm{kg}$ bw; i.p) and silymarin (25 $\mathrm{mg} / \mathrm{kg}$, i.p) as the standard reference drug, once in a day for 7 days respectively along with the intraperitoneal administration of $\mathrm{CCl}_{4}$ on day 1 and 7. Group V received only TLM $(200 \mathrm{mg} / \mathrm{kg}$; ip) once in a day for 7 days. At the end of 7 days, $24 \mathrm{~h}$ of the last treatment, all the animals were anesthetized in an ether chamber. The liver was removed and placed at $4^{\circ} \mathrm{C}$ after perfusion with ice cold saline. Intraperitoneal route of administration is selected because it is more rapid and predictable absorption than oral administration. This route is also advantageous because the drug is not inactivated or destroyed as may happen in the gastrointestinal tract and usually smaller doses are required because large concentrations of drug is achieved at the affected site. All experimental procedures involving animals were conducted in accordance with the guidelines of National Institutes of Health (NIH guidelines Islamabad, Pakistan). The study protocol was approved (No. 0241) by Ethical Committee of Quaid-iAzam University, Islamabad.

\section{Determination of in vivo antioxidant activity}

$10 \%$ homogenate of liver tissue was prepared in $100 \mathrm{mM}$ $\mathrm{KH}_{2} \mathrm{PO}_{4}$ buffer containing $1 \mathrm{mM}$ EDTA ( $\mathrm{pH}$ 7.4) and centrifuged at $12,000 \times \mathrm{g}$ for $30 \mathrm{~min}$ at $4^{\circ} \mathrm{C}$. The supernatant was collected and used for the following experiments as described below.

\section{Determination of thiobarbituric acid reactive substances (TBARS)}

Malondialdehyde in liver homogenate was determined by reaction with thiobarbituric acid (TBA). Briefly; 
$1.0 \mathrm{ml}$ reaction assay was consisted of $0.58 \mathrm{ml}$ phosphate buffer (0.1 M; pH 7.4), $0.2 \mathrm{ml}$ liver supernatant and following addition of $1.0 \mathrm{ml} 0.67 \%$ thiobarbituric acid, all the tubes were placed in boiling water bath for $20 \mathrm{~min}$ and then shifted to crushed ice-bath before centrifuging at $2500 \times \mathrm{g}$ for $10 \mathrm{~min}$. The amount of TBARS formed in each of the samples was assessed by measuring optical density of the supernatant at $535 \mathrm{~nm}$ using spectrophotometer against a reagent blank. The results were expressed as $\mathrm{nM}$ TBARS $/ \mathrm{min} / \mathrm{mg}$ tissue at $37^{\circ} \mathrm{C}$ using molar extinction coefficient of $1.56 \times 10^{5} \mathrm{M}^{-1} \mathrm{~cm}^{-1}[32]$.

\section{Determination of reduced glutathione (GSH)}

Reduced glutathione in liver homogenate was determined by reaction with 1,2-dithio-bis nitro benzoic acid (DTNB). Briefly, $1.0 \mathrm{ml}$ of supernatant was precipitated with $1.0 \mathrm{ml}$ of (4\%) sulphosalicylic acid. The samples were kept at $4^{\circ} \mathrm{C}$ for $1 \mathrm{~h}$ and then centrifuged at $1200 \times$ $\mathrm{g}$ for $20 \mathrm{~min}$ at $4^{\circ} \mathrm{C}$. The total volume of $3.0 \mathrm{ml}$ assay mixture contained $0.1 \mathrm{ml}$ filtered aliquot, $2.7 \mathrm{ml}$ phosphate buffer (0.1 M; pH 7.4) and $0.2 \mathrm{ml}$ of 1,2-dithio-bis nitro benzoic acid (DTNB, $100 \mathrm{mM}$ ). The yellow colour developed was read immediately at $412 \mathrm{~nm}$ on a SmartSpecTM plus Spectrophotometer. It was expressed as $\mu \mathrm{M} \mathrm{GSH} / \mathrm{g}$ tissue [33].

\section{Statistical analysis}

Data are expressed as mean \pm SD from three separate observations. For in vitro antioxidant assays one way ANOVA test followed by Tukey's test $(\mathrm{P}<0.05)$ was used to analyze the differences among $\mathrm{EC}_{50}$ of various fractions for different antioxidant assays. The $\mathrm{EC}_{50}$ values were determined using the Graph Pad Prism 5 software. Data on biochemical investigations of in vivo experiments were analyzed by one-way (ANOVA) and the group means were compared by Dunnet's Multiple Range Test. A probability of $\mathrm{P}<0.05$ was considered as significant.

\section{Results}

\section{Phytochemical screening}

Phytochemical screening of TLM demonstrated the presence of alkaloids, anthraquinones, cardiac glycosides, coumarins, flavonoids, saponins, phlobatannins, tannins and terpenoids.

\section{In vitro antioxidant activity}

Antioxidant capacity of TLM and its derived fractions was examined using seven different assays.

\section{DPPH radical scavenging activity}

Figure 1A shows that the scavenging effects of samples on DPPH radical and were in the following order: TLB > TLE $>$ TLC $>$ TLM $>$ TLA $>$ TLH. The $\mathrm{EC}_{50}$ values of scavenging DPPH radicals for the TLB and TLE were $41.0 \pm 1$ and $62.0 \pm 2 \mu \mathrm{g} / \mathrm{ml}$, respectively (Table 1 ). Though the antioxidant potential of fractions was found to be low $(\mathrm{P}<0.05)$ than those of ascorbic acid and rutin, the study revealed that TLB and TLE have prominent antioxidant activity; the presence of phenolic compounds (containing phenolic hydroxyls) are mainly found in these two fractions and could be attributable to the observed high antiradical properties of these fractions.

\section{Superoxide radical scavenging activity}

Superoxide radical is considered a major biological source of reactive oxygen species [34]. Although superoxide anion is a weak oxidant, it gives rise to generation of powerful and dangerous hydroxyl radicals as well as singlet oxygen, both of which contribute to oxidative stress [35]. The superoxide radical scavenging effect of different fractions was compared with the same doses of ascorbic acid ranging from $25-500 \mu \mathrm{g} / \mathrm{ml}$. The $\mathrm{EC}_{50}$ values in superoxide scavenging activities were in the order of TLM > TLC > TLB > TLE > TLA > TLH (Table 1). When compared to ascorbic acid; the superoxide scavenging activity of the extract was found to be low $(\mathrm{P}<0.05)$. In spite of this TLM and TLC $\left(\mathrm{EC}_{50} 55.0\right.$ \pm 0.3 and $68.0 \pm 2 \mu \mathrm{g} / \mathrm{ml}$ respectively) behave as powerful superoxide anion scavengers that may include therapeutic use against oxidative stress.

\section{Phosphomolybdate assay}

The phosphomolybdate method is quantitative, since the total antioxidant capacity (TAC) is expressed as ascorbic acid equivalents. The antioxidant capacity of various solvent fractions of T. leptophylla was found to decrease in this order: TLB $>$ TLC $>$ TLE $>$ TLM $>$ TLA $>$ TLH fraction (Table 1; Figure 1C). All results showed antioxidant activity in dose dependent manner at concentration 25 to $250 \mu \mathrm{g} / \mathrm{ml}$. The $\mathrm{EC}_{50}$ value of antioxidant capacity for the TLB $(10.7 \pm 2 \mu \mathrm{g} / \mathrm{ml})$ was most pronounced $(\mathrm{P}<0.05)$ than TLC $(135 \pm 4 \mu \mathrm{g} / \mathrm{ml})$ and TLE $(196 \pm 4 \mu \mathrm{g} / \mathrm{ml})$ (Table 1$)$. Strong antioxidant activity of TLB statistically similar to ascorbic acid indicates strong antioxidants in this fraction and these could be attributable to the presence of phenolic compounds.

\section{Hydroxyl radical scavenging activity}

Hydroxyl radical scavenging activity was quantified by measuring the inhibition of the degradation of 2deoxyribose by the free radicals generated by the Fenton reaction. The hydroxyl radical scavenging activity of $T$. leptophylla extract and its derived fractions can be ranked as TLC > TLE > TLB > TLM > TLH and TLA (Table 1). All fractions showed antioxidant activity in dose dependent manner at concentration $25-500 \mu \mathrm{g} / \mathrm{ml}$ (Figure 1D). In the present investigation, the $\mathrm{EC}_{50}$ value 

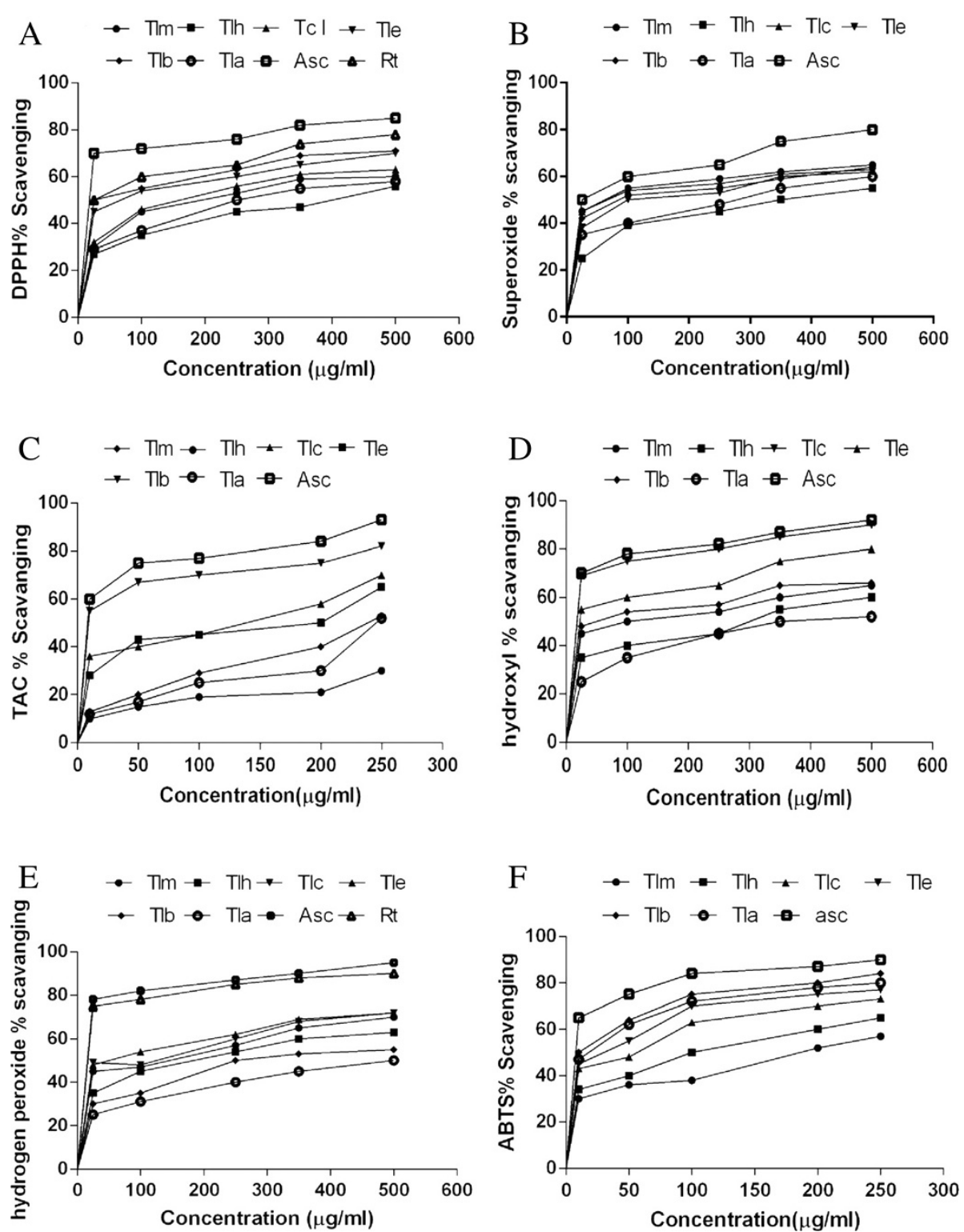

Figure 1 Antioxidant activities of different extracts from the methanol extract of whole plant of $T$. leptophylla by different solvents at various concentrations. Each value represents a mean \pm SD $(n=3)$ : (A) DPPH radical scavenging activity, (B) Superoxide radical scavenging activity, (C) Total antioxidant capacity, (D) Hydroxyl radical scavenging activity, (E) Hydrogen peroxide radical scavenging activity, (F) ABTS radical scavenging activity. TIm., methanol fraction, Tlh., $n$-hexane fraction, Tlc., chloroform fraction, Tle., ethyl acetate fraction, Tlb., $n$-butanol fraction, Tla., residual aqueous fraction, Asc., ascorbic acid, Rt., rutin.

of hydroxyl radical scavenging activity for the TLC and TLE was $8.0 \pm 1$ and $27.0 \pm 1 \mu \mathrm{g} / \mathrm{ml}$ while for TLB was $62.0 \pm 2 \mu \mathrm{g} / \mathrm{ml}$ (Table 1$)$. The markedly strong $(\mathrm{P}<0.05)$ antioxidant response of TLC and TLE in comparison with ascorbic acid might be helpful in characterizing the significant sources of natural antioxidant reaction.

\section{Hydrogen peroxide radical scavenging activity}

The scavenging effect of different fractions of $T$. leptophylla on hydrogen peroxide was concentration-dependent $(25-500 \mu \mathrm{g} / \mathrm{ml})$ as shown in Figure 1E. TLE displayed strong $\mathrm{H}_{2} \mathrm{O}_{2}$ scavenging activity $\left(\mathrm{EC}_{50} \quad 68.0 \pm 2 \mu \mathrm{g} / \mathrm{ml}\right)$ whereas that of the standard, ascorbic acid exhibited $9.0 \pm 0.3 \mu \mathrm{g} / \mathrm{ml}$. The scavenging activities of TLC and TLM were $\left(\mathrm{EC}_{50} 122 \pm 5 \mu \mathrm{g} / \mathrm{ml}\right.$ and $130 \pm 5 \mu \mathrm{g} / \mathrm{ml}$, respectively) (Table 1$). \mathrm{EC}_{50}$ values of the fractions in scavenging hydrogen peroxide were significantly different $(\mathrm{P}<0.05)$ from the $\mathrm{EC}_{50}$ values obtained for ascorbic acid. The scavenging activity for hydrogen peroxide of various solvent extracts from T. leptophylla was in the order of TLE $>$ TLC $>$ TLM $>$ TLH $>$ TLB $>$ TLA respectively. 
Table 1 Radical scavenging activities of $T$. leptophylla fractions at different concentrations

\begin{tabular}{|c|c|c|c|c|c|c|}
\hline \multicolumn{7}{|c|}{$\mathrm{EC}_{50}$ values $(\mu \mathrm{g} / \mathrm{ml})$ of radical scavenging } \\
\hline $\begin{array}{l}\text { Plant extracts/ } \\
\text { chemical }\end{array}$ & $\begin{array}{l}\text { DPPH } \\
\text { radical }\end{array}$ & $\begin{array}{l}\text { Superoxide } \\
\text { radical }\end{array}$ & $\begin{array}{l}\text { Phosphomolybdate } \\
\text { Assay }\end{array}$ & Hydroxyl radical & Hydrogen peroxide & ABTS radical \\
\hline Methanol extract & $189 \pm 4^{e}$ & $55.0 \pm 0.3^{d}$ & $236 \pm 1^{e}$ & $76.0 \pm 2^{d}$ & $130 \pm 5^{\mathrm{e}}$ & $\overline{179 \pm 3^{e}}$ \\
\hline$n$-Hexane fraction & $395 \pm 5^{f}$ & $370 \pm 4^{f}$ & $247 \pm 3^{e}$ & $281 \pm 2^{\mathrm{e}}$ & $200 \pm 2^{e}$ & $50.0 \pm 1^{c}$ \\
\hline Chloroform fraction & $162 \pm 3^{e}$ & $68.0 \pm 2^{d}$ & $135 \pm 4^{e}$ & $8.0 \pm 1^{\mathrm{a}}$ & $122 \pm 5^{e}$ & $57.0 \pm 2^{d}$ \\
\hline Ethyl acetate fraction & $62.0 \pm 2^{d}$ & $145 \pm 1^{e}$ & $196 \pm 4^{e}$ & $27.0 \pm 1^{b}$ & $68.0 \pm 2^{d}$ & $34.0 \pm 3^{b}$ \\
\hline n-Butanol fraction & $41.0 \pm 1^{c}$ & $92.0 \pm 1^{d}$ & $10.7 \pm 2^{\mathrm{a}}$ & $62.0 \pm 2^{d}$ & $254 \pm 3^{e}$ & $10.0 \pm 0.9^{a}$ \\
\hline $\begin{array}{l}\text { Residual aqueous } \\
\text { fraction }\end{array}$ & $264 \pm 4^{e}$ & $269 \pm 3^{e}$ & $237 \pm 3^{e}$ & $345 \pm 4^{f}$ & $431 \pm 5^{f}$ & $13.0 \pm 0.2^{\mathrm{a}}$ \\
\hline Ascorbic acid & $10.0 \pm 3^{\mathrm{a}}$ & $34.0 \pm 3^{b}$ & $8.0 \pm 0.7^{\mathrm{a}}$ & $6.0 \pm 2^{\mathrm{a}}$ & $9.0 \pm 0.3^{\mathrm{a}}$ & $8.0 \pm 1^{a}$ \\
\hline Rutin & $29.0 \pm 1^{b}$ & - & - & - & $10.0 \pm 0.3^{a}$ & - \\
\hline
\end{tabular}

Each value in the table is represented as mean $\pm S D(n=3)$. Values in the same column followed by a different letter $\left({ }^{a-f}\right)$ are significantly different $(p<0.05)$. - , not determined.

\section{ABTS radical scavenging activity}

All the fractions of T. leptophylla scavenged ABTS radical in a concentration-dependent way $(25-250 \mu \mathrm{g} / \mathrm{ml})$ (Figure 1F). Present results showed that the ABTS radical scavenging ability of samples can be ranked as TLB $>$ TLA > TLE > TLH > TLC > TLM. TLB and TLA exhibited prominent ABTS radical scavenging activities.

\section{Reducing power activity}

Figure 2 shows the dose response curves for the reducing powers of all extracts $(25-250 \mu \mathrm{g} / \mathrm{ml})$ from $T$. leptophylla. It was found that the reducing power increased with concentration of each sample. The ranking order for reducing power was TLM > TLB > TLC > TLA >

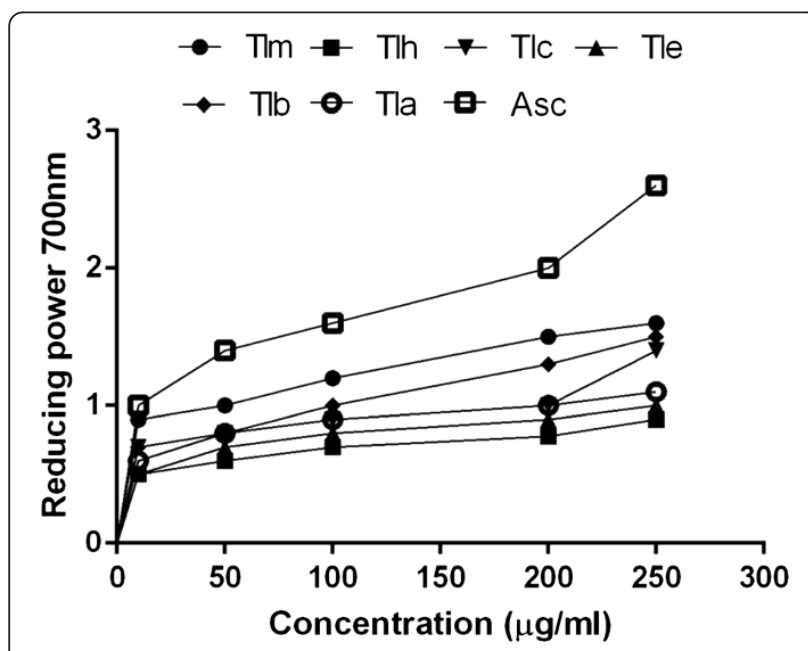

Figure 2 Reducing power of different extracts from the methanol extract of $T$. leptophylla by different solvents at different concentrations. Each value represents a mean $\pm S D(n=3)$. TIm., methanolic fraction, TIh., $n$-hexane fraction, Tlc., chloroform fraction, Tle., ethyl acetate fraction, Tlb., $n$-butanol fraction, Tla., residual aqueous fraction, Asc., ascorbic acid.
TLE > TLH. Significantly higher reducing power (1.47 \pm 0.14 at $250 \mu \mathrm{g} / \mathrm{ml}$ ) was evident in TLM fraction.

\section{Extraction yield, total phenolic and flavonoid contents}

The extraction yield of different fractions of T. leptophylla varied from $4.3 \pm 0.4$ to $11.5 \pm 1.6 \%$ with a descending order of TLM > TLA > TLE > TLH > TLB > TLC (Table 2). So the extraction with methanol resulted in the highest amount of total extractable compounds whereas the extraction yield with chloroform was only small in comparison with that of the other solvents.

Total phenolic content was estimated by using FolinCiocalteu reagent. Total phenolic content of the different fractions of $T$. leptophylla was solvent dependent and expressed as milligrams of gallic acid equivalents (GAE) equivalent. Table 2 summarizes that total phenolic compounds in fractions varied widely, ranging from $49.9 \pm 4.1$ and $121.9 \pm 3.1 \mathrm{mg} / \mathrm{g}$ expressed as gallic acid equivalents (GAE). TLM exhibited the highest total phenolic content. The content of flavonoid expressed as

Table 2 Total phenolics, flavonoid and extraction yield of methanol extract and soluble fractions of $T$. leptophylla

\begin{tabular}{lclr}
\hline $\begin{array}{l}\text { Plant } \\
\text { extracts }\end{array}$ & $\begin{array}{l}\text { Total } \\
\text { phenolics } \\
\text { (mg gallic } \\
\text { acid } \\
\text { equivalent/g) }\end{array}$ & $\begin{array}{l}\text { Total } \\
\text { flavonoid } \\
\text { (mg rutin } \\
\text { equivalent/g) }\end{array}$ & $\begin{array}{l}\text { Extraction } \\
\text { yield (\%) }\end{array}$ \\
\hline Methanol extract & $121.9 \pm 3.1^{\mathrm{c}}$ & $59.6 \pm 1.5^{\mathrm{c}}$ & $11.5 \pm 1.6^{\mathrm{d}}$ \\
n-Hexane fraction & $54.9 \pm 2.8^{\mathrm{a}}$ & $15.8 \pm 0.9^{\mathrm{a}}$ & $5.4 \pm 1.3^{\mathrm{b}}$ \\
Chloroform fraction & $78.0 \pm 1.1^{\mathrm{b}}$ & $26.0 \pm 1.9^{\mathrm{b}}$ & $4.3 \pm 0.4^{\mathrm{a}}$ \\
Ethyl acetate fraction & $80.0 \pm 5.2^{\mathrm{b}}$ & $60.9 \pm 2.2^{\mathrm{c}}$ & $6.1 \pm 0.8^{\mathrm{b}}$ \\
n-Butanol fraction & $80.9 \pm 2.9^{\mathrm{b}}$ & $55.0 \pm 2.5^{\mathrm{c}}$ & $4.8 \pm 1.1^{\mathrm{a}}$ \\
Residual aqueous & $49.9 \pm 4.1^{\mathrm{a}}$ & $14.9 \pm 0.4^{\mathrm{a}}$ & $8.2 \pm 0.9^{\mathrm{c}}$ \\
fraction & & & \\
\hline
\end{tabular}

Each value in the table is represented as mean $\pm S D(n=3)$. Values in the same column followed by a different letter $\left({ }^{a-d}\right)$ are significantly different $(P<0.05)$. 
rutin equivalents, varied from $14.9 \pm 0.4$ to $60.9 \pm 2.2 \mathrm{mg}$ rutin equivalent/g extract (Table 2). The TLE showed the highest amount of flavonoid contents followed by TLM and TLB.

\section{Correlation of $\mathrm{EC}_{50}$ values of antioxidant activities with TPC and TFC}

For total phenolic content a significant but marginal positive correlation $\left(R^{2}>0.7020, R^{2}>0.7458, R^{2}>\right.$ 0.6663 and $R^{2}>0.6777$ respectively) was found between TPC and $\mathrm{EC}_{50}$ values for $\mathrm{DPPH}$, hydroxyl, phosphomolybdate and ABTS respectively, while also another weak positive correlation was found between TFC and $\mathrm{EC}_{50}$ values for superoxide anion and hydroxyl radicals. However, a non significant correlation was found in case of hydrogen peroxide radical scavenging with both TPC and TFC (Table 3).

\section{In vivo antioxidant activity}

In vivo lipid peroxidation study reveals that rats of $\mathrm{CCl}_{4}$ treated group showed significant increase $(\mathrm{P}<0.05)$ in thiobarbituric acid reactive substances (TBARS) when compared with rats of normal control group. TLM and silymarin were able to significantly blunt $(\mathrm{P}<0.05)$ this rise in TBARS level (Table 4). There was a marked decrease in the level of $\mathrm{GSH}$ in $\mathrm{CCl}_{4}$ treated group when compared with normal control group. The GSH level was significantly increased $(\mathrm{P}<0.05)$ in TLM and silymarin treated groups (Table 4).

\section{Discussion}

Several techniques have been used to determine the antioxidant activity in vitro in order to allow rapid screening of substances since substances that have low antioxidant activity in vitro, will probably show little activity in vivo [8]. Free radicals are known to play a definite role in a wide variety of pathological manifestations. Antioxidants fight against free radicals and protect

Table 3 Correlations between the $\mathrm{EC}_{50}$ values of antioxidant activities and phenolic and flavonoids content of T. leptophylla

\begin{tabular}{lll}
\hline \multicolumn{1}{c}{ Assays } & \multicolumn{2}{c}{ Correlation $\mathbf{R}^{\mathbf{2}}$} \\
\cline { 2 - 3 } & Phenolics & Flavonoid \\
\hline $\mathrm{EC}_{50}$ of DPPH radical scavenging ability & $0.7020^{*}$ & 0.192 \\
$\mathrm{EC}_{50}$ of superoxide radical scavenging ability & 0.1905 & $0.6613^{*}$ \\
$\mathrm{EC}_{50}$ of phosphomolybdate antioxidant capacity & $0.6663^{*}$ & 0.4306 \\
$\mathrm{EC}_{50}$ of hydroxyl radical scavenging ability & $0.7458^{*}$ & $0.7215^{*}$ \\
$\mathrm{EC}_{50}$ of hydrogen peroxide radical scavenging & 0.0194 & 0.0126 \\
ability & & \\
$\mathrm{EC}_{50}$ of ABTS radical scavenging ability & $0.6777^{*}$ & 0.1285 \\
\hline
\end{tabular}

Each value in the table is represented as mean $\pm S D(n=3)$. ${ }^{*}$ indicates significance at $P<0.05$.
Table 4 Effects of TLM on hepatic protein, lipid peroxidation (TBARS) and glutathione (GSH)

\begin{tabular}{llll}
\hline Group & $\begin{array}{l}\text { Protein } \\
(\boldsymbol{\mu} \mathbf{g} / \mathbf{m g} \text { tissue) }\end{array}$ & $\begin{array}{l}\text { TBARS } \\
(\mathbf{n M} / \mathbf{m g} \text { protein) }\end{array}$ & $\begin{array}{l}\text { GSH } \\
(\boldsymbol{\mu} \mathbf{g} / \mathbf{m g} \text { protein })\end{array}$ \\
\hline 1 & $1.697 \pm 0.024+$ & $3.43 \pm 0.53+$ & $31.34 \pm 1.10+$ \\
II & $0.657 \pm 0.021^{*}$ & $6.39 \pm 0.98^{*}$ & $15.99 \pm 1.67^{*}$ \\
III & $1.563 \pm 0.092^{*}+$ & $4.30 \pm 0.91^{*}+$ & $26.68 \pm 1.16^{*}+$ \\
IV & $1.509 \pm 0.003+$ & $4.69 \pm 0.74^{*}+$ & $27.42 \pm 1.21^{*}+$ \\
$V$ & $1.702 \pm 0.012+$ & $3.67 \pm 0.42+$ & $29.97 \pm 1.12+$ \\
\hline
\end{tabular}

Group I: Controls (Olive oil+ DMSO); II: $\mathrm{CCl}_{4}(3 \mathrm{ml} / \mathrm{kg}$ bw); Ill: TLM (200 mg/kg bw) $+\mathrm{CCl}_{4}(3 \mathrm{ml} / \mathrm{kg} \mathrm{bw}) ; \mathrm{IV}$ : Silymarin $(50 \mathrm{mg} / \mathrm{kg} \mathrm{bw})+\mathrm{CCl}_{4}(3 \mathrm{ml} / \mathrm{kg} \mathrm{bw}) ; \mathrm{V}$ : TLM (200 mg/kg bw).

TLM; methanol extract of $T$. leptophylla.

Values are Mean \pm SD (06 numbers).

*, Indicate significance from control group $(\mathrm{P}<0.05)$.

+ , Indicate significance from $\mathrm{CCl}_{4}$ group $(\mathrm{P}<0.05)$.

us from various diseases. They exert their action either by scavenging the reactive oxygen species or protecting the antioxidant defense mechanisms [21].

The electron donation ability of natural products can be measured by $2,2^{\prime}$-diphenyl-1- picrylhydrazyl radical (DPPH) purple-coloured solution bleaching [8]. The method is based on scavenging of DPPH through the addition of a radical species or antioxidant that decolourizes the DPPH solution. The degree of colour change is proportional to the concentration and potency of the antioxidants. A large decrease in the absorbance of the reaction mixture indicates significant free radical scavenging activity of the compound under test [36]. In the present study among all the fractions tested, $n$-butanol, chloroform and ethyl acetate showed significantly higher inhibition percentage and positively correlated with total phenolic content. Results of this study suggest that the plant extract contain phytochemical constituents that are capable of donating hydrogen to a free radical to scavenge the potential damage.

Superoxide radical is considered a major biological source of reactive oxygen species [34]. Although superoxide anion is a weak oxidant, it gives rise to generation of powerful and dangerous hydroxyl radicals as well as singlet oxygen, both of which contribute to oxidative stress [35]. The results of our study revealed that TLM, TLC and TLB had effective capacity of scavenging for superoxide radical and correlated with total flavonoid content thus suggesting its antioxidant potential.

The antioxidant capacity of the fractions was measured spectrophotometrically through phosphomolybdenum method, based on the reduction of Mo (VI) to Mo (V) by the test sample and the subsequent formation of green phosphate/Mo (V) compounds with a maximum absorption at $765 \mathrm{~nm}$. The present study demonstrated that TLB exhibited the highest antioxidant capacity for phosphomolybdate reduction. Recent studies have shown that many flavonoid and related polyphenols 
contribute significantly to the phosphomolybdate scavenging activity of medicinal plants $[37,38]$.

Hydroxyl radical is one of the potent reactive oxygen species in the biological system. It reacts with polyunsaturated fatty acid moieties of cell membrane phospholipids and causes damage to cell [5,39]. The hydroxyl radical is regarded as a detrimental species in pathophysiological processes and capable of damaging almost every molecule of biological system and contributes to carcinogenesis, mutagenesis and cytotoxicity [40]. Hydroxyl radicals were produced by the reaction of $\mathrm{H}_{2} \mathrm{O}_{2}$ and the ferrous that would react with 2-deoxyribose. The reaction was stopped by adding TBA reagent that would give a red colour if the malonaldehyde was formed as the result of the reaction between the radical and 2-deoxyribose. Hydroxyl radical scavenging capacity of an extract is directly proportional to its antioxidant activity which is depicted by the low intensity of red colour [41]. All fractions of T. leptophylla when added to the reaction mixture actively scavenged the hydroxyl radicals and prevented the degradation of 2-deoxyribose.

Hydrogen peroxide occurs naturally at low concentration levels in the air, water, human body, plants, microorganisms and food [41]. $\mathrm{H}_{2} \mathrm{O}_{2}$ is rapidly decomposed into oxygen and water and this may produce hydroxyl radicals $(\bullet \mathrm{OH})$ that can initiate lipid peroxidation and cause DNA damage [42]. Ethyl acetate fraction of T. leptophylla efficiently scavenged hydrogen peroxide which may be attributed to the presence of phenolic groups that could donate electrons to hydrogen peroxide, thereby neutralizing it into water.

ABTS radical scavenging assay involves a method that generates a blue/green $\mathrm{ABTS}^{+}$chromophore via the reaction of ABTS and potassium persulfate. The ABTS radical cation is generated by the oxidation of ABTS with potassium persulfate, its reduction in the presence of hydrogen-donating antioxidants is measured spectrophotometrically at $745 \mathrm{~nm}$. All the fractions possessed strong ABTS scavenging activity an observation that is supported by other researchers [43].

In reducing power assay, the yellow colour of the test solution changes to green depending on the reducing power of the test specimen. The presence of the reductants in the solution causes the reduction of the $\mathrm{Fe}^{3+} /$ ferricyanide complex to the ferrous form. Therefore, $\mathrm{Fe}^{2+}$ can be monitored by absorbance measurement at $700 \mathrm{~nm}$. Previous reports suggested that the reducing properties have been shown to exert antioxidant action by donating of a hydrogen atom to break the free radical chain [44]. Increasing absorbance at $700 \mathrm{~nm}$ indicates an increase in reducing ability. The antioxidants present in the fractions of T. leptophylla caused their reduction of $\mathrm{Fe}^{3+}$ / ferricyanide complex to the ferrous form, and thus proved the reducing power.
Plant materials rich in phenolics are increasingly being used in the food industry because they retard oxidative degradation of lipids and improve the quality and nutritional value of food [45]. Phenolic compounds are considered secondary metabolites and these phytochemical compounds derived from phenylalanine and tyrosine occur ubiquitously in plants and are diversified [46]. The methanol extract exhibited the highest total phenolics content, whereas the contents obtained with residual aqueous fraction were much smaller that is in agreement with other reports [47]. Phenolic compounds of plants are also very important because their hydroxyl groups confer scavenging ability.

Phenolic compounds of plants fall into several categories; chief among these are the flavonoids which have potent antioxidant activities [8]. Flavonoids are naturally occurring in plants and are thought to have positive effects on human health. Studies on flavonoidic derivatives have shown a wide range of antibacterial, antiviral, anti inflammatory, anticancer, and anti-allergic activities $[48,49]$. Flavonoids have been shown to be highly effective scavengers of most oxidizing molecules, including singlet oxygen, and various free radicals [50] implicated in several diseases. So comparable with the findings in the literature for other extracts of plant products [42] our results suggested that phenolic acids and flavonoids may be the major contributors for the antioxidant activity as the $\mathrm{EC}_{50}$ values of radical scavenging activity of various soluble fractions of T. leptophylla and the contents of phenolics or flavonoids exhibited significant correlation. However, non significant correlation was found in case of hydrogen peroxide radical scavenging. It is known that different phenolic compounds have different responses in the Folin-Ciocalteu method. Similarly the molecular antioxidant response of phenolic compounds varies remarkably, depending on their chemical structure [51]. In addition, there may be some interference rising from other chemical components present in the extract, such as sugars or ascorbic acid [52].

Liver damage is very common since liver has to detoxicate a lot many toxic substances. There are several chemicals that have been known to induce hepatotoxicity by producing the reactive species which form covalent bonds with the lipids of the tissue [53,54]. Liver injury due to $\mathrm{CCl}_{4}$ in rats was first reported in 1936 [55] and has been widely and successfully used by many investigators [56,57]. Carbon tetrachloride is metabolized by cytochrome P-450 in endoplasmic reticulum and mitochondria with the formation of $\mathrm{CCl}_{3} \mathrm{O}^{-}$, a reactive oxidative free radical, which initiates lipid peroxidation $[58,59]$.

A large reserve of reduced glutathione is present in hepatocytes for detoxification of free radicals. However, oxidative stress results in toxicity when the rate at which 
the ROS are generated exceeds the cell capacity for their removal $[60,61]$. Most hepatotoxic chemicals damage liver by inducing, directly or indirectly, lipid peroxidation. MDA is one of the end products in the lipid peroxidation process [62]. In our in vivo study elevation in levels of end products of lipid peroxidation in liver of rats treated with $\mathrm{CCl}_{4}$ were observed. The increase in MDA levels in liver suggests enhanced lipid peroxidation leading to tissue damage [63]. Treatment with TLM significantly reversed these changes. Hence it may be possible that the mechanism of hepatoprotection of extract is due to its antioxidant effect [63].

GSH is an intracellular reductant and protects cells against free radicals, peroxides and other toxic compounds. GSH is a naturally occurring substance that is abundant in many living creatures; GSH depletion increases the sensitivity of cells to various aggressions leading to tissue disorder and injury [64]. In the present study we demonstrated the effectiveness of the extract by using $\mathrm{CCl}_{4}$ induced rats and found that exogenous TLM supplementation elevated GSH levels in rats with $\mathrm{CCl}_{4}$ treatment and thus might provide a mean of recovering reduced GSH levels and to prevent tissue disorders and injuries. Therefore, it is valid to consider that TLM, because of its antioxidant property as the extract has confirmed the presence of saponins, might be capable of protecting the hepatic tissue from $\mathrm{CCl}_{4}$-induced injury and inflammatory changes. Saponins are natural products, which have been shown to possess antioxidant properties $[65,66]$.

\section{Conclusion}

The replacement of synthetic with natural antioxidants (because of implications for human health) may be advantageous. In the present study analysis of free radical scavenging activity and total phenolic and flavonoid content showed that mainly the TLB, TLC, TLE and TLM from the whole plant of $T$. leptophylla can be the potent source of natural antioxidants. The results of in vivo studies suggest that methanolic extract of T. leptophylla may be useful in defense against $\mathrm{CCl}_{4}$-induced liver damage possibly be due to its antioxidant properties.

\section{Competing interests}

The authors declare that they have no competing interests.

\section{Authors' contributions}

NS made significant contribution to acquisition of data, analysis, drafting of the manuscript. MRK has made substantial contribution to conception and design, interpretation of data, drafting and revising the manuscript for intellectual content. MS participated in the design and collection of data and analysis. All authors read and approved the final manuscript.

Received: 18 June 2012 Accepted: 12 November 2012

Published: 16 November 2012

\section{References}

1. Maqsood S, Singh P, Samoon MH, Balange AK: Effect of dietary chitosan on non-specific immune response and growth of Cyprinus carpio challenged with Aeromonas hydrophila. Inter Aqua Res 2010, 2:77-85.

2. Zengin G, Cakmak YS, Guler GO, Aktumsek A: Antioxidant properties of methanolic extract and fatty acid composition of Centaurea urvillei DC. subsp. hayekiana Wagenitz. Rec Nat Prod 2011, 5:123-132.

3. Vongtau HO, Abbah J, Chindo BA, Mosugu O, Salawu AO, Kwanashie HO, Gamaniel KS: Central inhibitory effects of the methanol extract of Neorautanenia mitis root in rats and mice. J Pharm Biol 2005, 43:113-120.

4. Oluyemi KA, Okwuonu UC, Baxter DG, Oyesola TO: Toxic effects of methanolic exract of Aspilia africana leaf on the estrous cycle and uterine tissues of Wistar rats. Int J Morphol 2007, 25:609-614.

5. Halliwell B, Gutteridge JMC: Formation of thiobarbituric acid reactive substances from deoxyribose in the presence of iron salts: the role of superoxide and hydroxyl radicals. FEBS Lett 1981, 128:347-352.

6. Gulcin I: Antioxidant activity of food constituents: an overview. Arch Toxicol 2012, 86:345-391.

7. Gocer H, Gulcin I: Caffeic acid phenethyl ester (CAPE): correlation of structure and antioxidant properties. Int J Food Sci Nutr 2011, 62:821-825.

8. Nunes PX, Silva SF, Guedes RJ, Almeida S: Biological oxidations and antioxidant activity of natural products, Phytochemicals as nutraceuticals Global Approaches to Their Role in Nutrition and Health. 2012.

9. Djeridane A, Yousfi M, Nadjemi B, Boutassouna D, Stocker P, Vidal N: Antioxidant activity of some Algerian medicinal plants extracts containing phenolic compounds. Food Chem 2006, 97:654-660.

10. Wannes WA, Mhamdi B, Sriti J, Jemia MB, Ouchikh O, Hamdaoui G, Kchouk ME, Marzouk B: Antioxidant activities of the essential oil and methanol extracts from myrtle (Myrtus communis var. italica L.) leaf, stem and flower. Food Chem Toxicol 2010, 48:1362-1370.

11. Harman D: Free radical theory of aging. Current status. Amster-dam: Elsevier; 1998:p. 3-p. 7.

12. Osawa T, Kavakishi S, Namiki M, Kuroda Y, Shankal DM, Waters MD: Antimutagenesis and anticarcinogenesis mechanisms II. New York: Plenum; 1990:139-153.

13. Govind P: Medicinal plants against liver diseases. IJPR 2011, 2:115-121.

14. Baranski R, Baranska M, Schulz H, Simon PW, Nothnaged T: Single seed roman measurements allow taxonomical discrimination of Apiaceae accessions collected in gene banks. Biopolymers 2006, 81:497-505.

15. Bigdeli M, Rustaiyan A, Masoudi S: Composition of the essential oil of Torilis arvensis (Huds). Link from Iran. J Essential Oil Res 2004, 16:526-527.

16. Maleki S, Seyyednejad SM, Damabi NM, Motamedi H: Antibacterial activity of the fruits of Iranian Torilis leptophylla against some clinical pathogens. Pak J Biol Sci 2008, 11:1286-1289.

17. Kil HY, Seong ES, Ghimire BK, Chung IM, Kwon SS, Goh EJ, Hoe K, Kim MJ, Lim JD, Lee D, Yu CY: Antioxidant and antimicrobial activities of crude sorghum extract. Food Chem 2009, 115:1234-1239.

18. Brand-Williams W, Cuvelier ME, Berset C: Use of free radical method to evaluate antioxidant activity. Lebensmittel-Wissenschaft und-Technol 1995, 28:25-30.

19. Bursal E, Gulcin I: Polyphenol contents and in vitro antioxidant activities of lyophilized aqueous extract of kiwifruit (Actinidia deliciosa). Food Res Int 2011, 44:1482-1489.

20. Beauchamp C, Fridovich I: Superoxide dismutase: improved assays and an assay applicable to acrylamide gels. Anal Biochem 1971, 44:276-277.

21. Umamaheswari $M$, Chatterjee TK: In vitro antioxidant activities of the fractions of Coccinnia grandis L. leaf extract. Afr J Trad Compl Altern Med 2008, 5:61-73

22. Nlavarasan R, Mallika M, Venkataraman S: Anti-inflammation and antioxidant activities of Cassia fistula Linn. bark extracts. Afr J Trad Compl Altern Med 2005, 2:70-85.

23. Ruch RJ, Cheng S-J, Klaunig JE: Prevention of cytotoxicity and inhibition of intercellular communication by antioxidant catechins isolated from Chinese green tea. Carcinogenesis 1989, 10:1003-1008.

24. Re R, Pellegrini N, Proteggente A, Pannala A, Yang M, Rice-Evans C: Antioxidant activity applying an improved $A B T S$ radical cation decolourisation assay. Free Rad Biol Med 1999, 26:1231-1237.

25. Gulcin I, Topal F, Cakmakc R, Bilsel M, Goren AC, Erdogan U: Pomological features, nutritional quality, polyphenol content analysis and antioxidant properties of domesticated and three wild ecotype forms of raspberries (Rubus idaeus L.). J Food Sci 2011, 76:585-593. 
26. Fejes S, Blazovics A, Lugasi A, Lemberkovics E, Petri G, Kery A: In vitro antioxidant activity of Anthriscus cerefolium L. (Hoffm.) extracts. J Ethnopharmacol 2000, 69:259-265.

27. Kim DO, Jeong SW, Lee CY: Antioxidant capacity of phenolic phytochemicals from various cultivars of plums. Food Chem 2003, 81:321-326.

28. Park Y-S, Jung S-T, Kang S-G, Heo BK, Arancibia-Avila P, Toledo F, Drzewiecki J, Namiesnik J, Gorinstein S: Antioxidants and proteins in ethylene-treated kiwifruits. Food Chem 2008, 107:640-648.

29. Harborne JB: Phytochemical methods. London: Chapman and Hall, Ltd; 1973: pp. 49-pp. 188.

30. Trease GE, Evans WC: Pharmacognsy. 11th edition. London: Brailliar Tiridel Can Macmillian Publishers; 1989:60-75.

31. Sofowara AE: Medicinal plants and traditional medicine in Africa. 2nd edition. Ibadan, Nigeria: Spectrum books Ltd.; 1993:289.

32. Iqbal M, Sharma SD, Zadeh HR, Hasan N, Abdulla M, Athar M: Glutathione metabolizing enzymes and oxidative stress in ferric nitrilotriacetate (Fe- NTA) mediated hepatic injury. Redox Rep 1996, 2:385-391.

33. Jollow DJ, Mitchell JR, Zampaglione N, Gillete JR: Bromobenzene induced liver necrosis. Protective role of glutathione and evidence for 3 , 4- bromobenzene oxide as a hepatotoxic metabolite. Pharmacology 1974, 1:151-169.

34. Alves CQ, David JM, David JP, Bahia MV, Aguiar RM: Methods for determination of in vitro antioxidant activity for extracts and organic compounds. Química Nova 2010, 33:2202-2210.

35. Meyer AS, Isaksen A: Application of enzymes as food antioxidants. Trends Food Sci Tech 1995, 1995(6):300-304.

36. Krishnaiah D, Sarbatly R, Nithyanandam RR: A review of the antioxidant potential of medicinal plant species. Food Bioprod Process 2011, 89:217-233.

37. Sharififar F, Dehghn-Nudeh G, Mirtajaldini M: Major flavonoids with antioxidant activity from Teucrium polium L. Food Chem 2009, 112:885-888.

38. Khan RA, Khan MR, Sahreen S: Assessment of flavonoids contents and in vitro antioxidant activity of Launaea procumbens. Chem Central J 2012 6:43.

39. Khan RA, Khan MR, Sahreen S, Ahmed M: Evaluation of phenolic contents and antioxidant activity of various solvent extracts of Sonchus asper (L.) Hill. Chem Central J 2012, 6:12.

40. Babu BH, Shylesh BS, Padikkala J: Antioxidant and hepatoprotective effect of Alanthus icicifocus. Fitoterapia 2001, 72:272-277.

41. Gulcin I, Berashvili D, Gepdiremen A: Antiradical and antioxidant activity of total anthocyanins from Perilla pankinensis decne. J Ethnopharmacol 2005, 101:287-293.

42. Sahreen S, Khan MR, Khan RA: Phenolic compounds and antioxidant activities of Rumex hastatus D. Don. Leaves. J Med Plants Res 2011, 5:2755-2765.

43. Sahreen S, Khan MR, Khan RA: Evaluation of antioxidant activities of various solvent extracts of Carissa opaca fruits. Food Chem 2010 122:1205-1211.

44. Gordon MH: The mechanism of antioxidant action in vitro. In Food antioxidants. Edited by Hudson BJ. London: Elsevier Applied Science; 1990: pp. 1-pp. 18.

45. Kähkönen MP, Hopia Al, Vuorela HJ, Rauha JP, Pihlaja K, Kujala TS, Heinonen M: Antioxidant activity of plant extracts containing phenolic compounds. J Agri Food Chem 1999, 1999(47):3954-3962.

46. Naczk M, Shahidi F: Extraction and analysis of phenolics in food. $J$ Chromatogr A 2004, 1054:95-111.

47. Ao C, Li A, Elzaawely AA, Xuan DT, Twata S: Evaluation of antioxidant and antibacterial activities of Ficus microcarpa L. fill extract. Food Contrl 2008, 19:940-948.

48. Di Carlo G, Mascolo N, Izzo AA, Capasso F: Flavonoids: old and new aspects of a class of natural therapeutic drugs. Life Sci 1999, 65:337-353.

49. Montoro P, Braca A, Pizza C, De Tommasi N: Structure-antioxidant activity relationships of flavonoids isolated from different plant species. Food Chem 2005, 92:349-355.

50. Bravo L: Polyphenols: chemistry, dietary sources, metabolism and nutritional significance. Nutr Reviews 1998, 56:317-333.

51. Satue-Gracia MT, Heinonen M, Frankel EN: Antioxidant activity of anthocyanin in LDL and lecithin liposome systems. J Agric Food Chem 1997, 1997(45):3362-3367.
52. Singleton $\mathrm{VL}$, Rossi JA: Colourimetry of total phenolics with phosphomolybdic-phosphotungstic acid reagents. Am J Enol Vitic 1965, 16:144-158.

53. Deshwal N, Sharma1 AK, Sharma P: Review on hepatoprotective plants. IJPSR 2011, 7:15-26.

54. Amartya GK, Partha G, Upal MK, Shibnath G: Hepatoprotective \& antioxidant effect \& stereoidal saponins of solanum of Solanum xanthocarpum and Solanum nigrum in paracetomol induce hepatotoxicity in rats. Pharmacologyonline 2009, 1:757-768.

55. Cameron GR, Thomas JC, Karunarathe WAE: The pathogenesis of liver injury in carbon tetrachloride and thioacetamide poisioning. J Path Bact 1936, 41:297.

56. Handa SS, Sharma A: Hepatoprotective activity of andrographolide from Andrographis paniculata against carbon tetrachloride. Ind J Med Res 1990, 92:276-292.

57. Shirwaiker A, Sreenivasan KK, Krishnanand BR, Kumar AV: Chemical investigation and anti hepatotoxic activity of the root bark of Caparis spinos. Fitoterapia 1996, 67:200-204

58. Zimmerman MD, Hayman J: Function and integrity of the liver, In: Clinical diagnosis and management by laboratory methods In: Clinical diagnosis and management by laboratory methods. 17th edition. 1976:217-250.

59. Agarwal AK, Mehendale JK: Potentiation of carbon tetrachloride hepatotoxicity and lethality by chlordecone in female rats. Toxicology 1983, 26:231-242.

60. Ghosh T, Maity TK, Das M, Bose A, Dash D: In vitro antioxidant and hepatoprotective activity of ethanolic extract of Bacopa monnieri L. aerial parts. IJPT 2007, 6:77-85.

61. Kurata M, Suzuki M, Agar NS: Antioxidant systems and erythrocyte life span in mammals. Biochem Physiol 1993, 106:477-487.

62. Asha W: Preliminary studies on hepatoprotective activities of Momordica sabangulata and Naragama alat. Indian J Pharmacol 2001, 33:276-279.

63. Khan MR, Marium A, Shabbir M, Saeed N, Bokhari J: Antioxidant and hepatoprotective effects of Oxalis corniculata against carbon tetrachloride $\left(\mathrm{CCl}_{4}\right)$ induced injuries in rat. Afr J Pharm Pharmacol 2012 6:2255-2267.

64. Jollow DJ: Glutathione thresholds in reactive metabolite toxicity. Arch Toxicol Supp/ 1980, 3:95-110.

65. Yoshiki Y, Okubo K: Active oxygen scavenging activity of $\operatorname{DDMP}(2,3-$ dihydro-2, 5-dihydroxy-6-methyl-4H-pyran-4-one) saponin in soybean seed. Biosci Biotech Biochem 1995, 59:56-57.

66. Hu J, Lee SO, Hendrich S, Murphy PA: Quantification of the group B soyasaponins by high-performance liquid chromatography. J Agri Food Chem 2002, 50:87-94.

doi:10.1186/1472-6882-12-221

Cite this article as: Saeed et al: Antioxidant activity, total phenolic and total flavonoid contents of whole plant extracts Torilis leptophylla L. BMC Complementary and Alternative Medicine 2012 12:221.

\section{Submit your next manuscript to BioMed Central and take full advantage of:}

- Convenient online submission

- Thorough peer review

- No space constraints or color figure charges

- Immediate publication on acceptance

- Inclusion in PubMed, CAS, Scopus and Google Scholar

- Research which is freely available for redistribution 